\title{
The Development of Economic Learning Model through CTL (Contextual Teaching and Learning) to Promote Students' Critical Thinking Skill
}

\author{
Sudarmiani \\ Universitas PGRI Madiun, Indonesia \\ aniwidjiati@unipma.ac.id
}

\begin{abstract}
This study aimed to describe the economic learning model that has been used in Islamic Senior High School 2 Madiun, the development of economic learning models through the CTL (Contextual Teaching and Learning) approach, and the results of research and development in economic learning model through the CTL (Contextual Teaching and Learning) approach to improve students' critical thinking skills. This study was research and development with the ADDIE approach which consists of Analysis, Design, Development, Implementation, and Evaluation. Based on the result of the analysis stage, the economic learning in Islamic Senior High School 2 Madiun was relatively conventional and yet using innovative models in economic learning. So then the innovation in the economic learning model aimed to improve students' critical thinking skills which still relatively low. Based on the results of preliminary studies and development stage, the design of economic learning models through the CTL (Contextual Teaching and Learning) approach is more effective and innovative in implement the economic learning process, especially in improving students' learning outcomes and critical thinking skills in Islamic Senior High School 2 Madiun.
\end{abstract}

\section{Keywords}

economic learning model; CTL (Contextual Teaching and Learning); critical

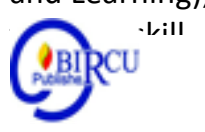

\section{Introduction}

Education has an important role in human survival, education has the purpose of developing intelligence, skills, and the potential of Indonesian young generation which are beneficial for themselves and their environment. According to Siswoyo (2008), education is a communication process that includes the transformation of knowledge, values, and skills, which occur inside and outside of school and lasts a long life (life long process) between generations, and education is useful for the lives of individuals, community environment, and the nation. In the education process, learning activities are the most important aspect of achieving these educational goals. Among the many ways to make it happen, one of them is through economic learning in schools. According to Rangkuti (2019) Education is a very fundamental human phenomenon and also has constructive traits in human life. That's why we are required to be able to hold a scientific reflection on education, as a responsibility for the actions taken, namely educating and being educated. 1

Economic learning in schools, especially at the high school level has the purpose to develop students' abilities in exercise economic activities by recognizing various realities and events that exist in society. Through economic learning, students are trained to understand concepts, theories, and solve various economic problems that occur in society. According to the Ministry of National Education (2003), the purpose of economic subjects is to develop students' ability to economize through how to recognize various economic facts and events, understand concepts and theories and practice in solving problems, especially economic 
problems that occur in the community. Meanwhile, Suchatiningsih (2006) stated that economic learning in high school has the aim that students can recognize their social environment so they can adjust to the environment they are living in and have a sensitivity to the economic events that occur around them.

However, based on research findings in schools, economic learning in the classroom has not been fully able to meet the needs of students in facing the challenges of the times. According to students, economic learning requires high concentration, so that it causes boredom and decreases student interest in learning. The use of lecture learning models was allegedly the main factor of learning to be less attractive because students were not actively involved during the learning activities. This is confirmed by Pratiwi's research (2013), the majority of students consider economic learning to be less interesting and tend to be boring. Economic learning is considered difficult to understand because of the lack of empirical certainty that is easily found in everyday life. Meanwhile, Arima Sari (2017), stated that most of the students' difficulties during the economic learning process are due to the lack of student interest in learning, the low ability of students to understand the concepts and the application of learning models that are not following the needs of students in school and their daily environment.

In addition to economic learning models that are less innovative, teachers tend to dominate the learning activities so students have less opportunity to develop their thinking skills. The inability of students to master economic learning competencies is the low economic learning outcomes of students due to the learning process that is applied only to measure cognitive abilities so that most students learn to think of economics as a difficult and boring lesson and the lack of students' ability to think in examine and answer existing problems (Sitorus, 2019). According to Dahar (2011), learning with the lecture and rote learning methods merely teach students to master the concepts without understanding the meaning and students who learn by rote method relatively have low order thinking skills. Eriawaty (2009) stated that economic learning models in schools have so far tended to be conventional using expository models, such as lectures, questions and answers, and group discussions, so it does not lead to the development of critical thinking skills in students. Meanwhile, according to Rois (2002), the process of economic learning in which teachers who usually act as informants and students as listeners tends to make the development process of students' thinking at a low level, thus are memorization and remembering. According to Johnson (2010), critical thinking is the ability to think logically that is applied to assess conditions and make good decisions. Fisher (2009) stated that critical thinking skills in economic learning are important to develop because it directs students' mindset in socializing and build sensitivity to the economic issues around them.

Therefore, to make students more active in economic learning and have high critical thinking skills, it is necessary to plan systematic economic learning following nowadays developments so that students have a more meaningful learning experience. This opinion is in line with Eriawaty's research (2009), the use of learning models must be flexible and lead to students' understanding and their direct experience in daily life so it will enhance students' critical thinking skills. According to Qomariah \& Sudarditha (2016), the learning model is one of the components in determining the success of student learning activities in class. The thing that needs to be noted by teachers is the ability to develop various effective and efficient learning models. A model that can be used to improve students' critical thinking skills is the CTL (Contextual Teaching and Learning) approach. 
According to Trianto (2008), the CTL (Contextual Teaching and Learning) approach is a learning concept that helps teachers to connect the teaching material with students' real-life sphere and encourage the relationship between students' knowledge and its application in life as the community member. According to Irwandi (2014), one of the characteristics of the CTL (Contextual Teaching and Learning) approach is that students are trained to achieve high standards, critical and creative thinking. Meanwhile, Suyadi (2013) stated that the CTL (Contextual Teaching and Learning) approach is a learning strategy that emphasizes student involvement to find relationships between material and real-life realities, thereby encouraging students to apply it in everyday life.

Based on the problems above, this study aims to develop an economic learning model using the CTL (Contextual Teaching and Learning) approach. The development of CTL (Contextual Teaching and Learning) approach is aimed to increase students' interest, learning outcomes and critical thinking skills, which have so far tend to be at low level. Through this model development, students are expected to be more sensitive to various economy issues that exist in schools and their community environment. The subject and place of research were conducted in 11th grade Social Studies of Islamic Senior High School 2 Madiun.

\section{Research Methods}

This study used the research and development method in developing economic learning models through the CTL (Contextual Teaching and Learning) approach (Sugiyono, 2015). The research and development method was used to produce and test the effectiveness of economic learning models which aimed to improve students' critical thinking skills. The procedure of research and development used for developing the economic learning model was the ADDIE which consists of Analysis, Design, Development, Implementation, and Evaluation stage.

\subsection{Analysis}

This stage was carried out by conducting a preliminary analysis to determine the process of economic learning in the classroom, the learning model used by the teacher in teaching, students' creative thinking skills, and an analysis of the developed economic learning model.

\subsection{Design}

This stage was carried out by designing an initial form of economic learning model which was adapted to the learning material as well as the Core Competence and Basic Competence of economic subjects in the 2013 curriculum. This stage conducted so that the model of economic learning through the CTL (Contextual Teaching and Learning) approach can be implemented in the learning process in 11th grade Social Studies.

\subsection{Development}

This stage was carried out by conducting a feasibility test on an economic learning model developed through a validation test consisting of two learning model experts namely Prof. Dr. Nunuk Suryani, M.Pd and Prof. Dr. Abdul Gafur, M.Sc. Validation tests were also conducted by two experts on learning materials and linguists namely Prof. Sariyatun, M.Pd., M.Hum., And Dr. Bambang Eko Hari Cahyono, M.Pd.

\subsection{Implementation}

This stage was a trial model of economic learning through the CTL (Contextual Teaching and Learning) approach in the trial class by conducted two trials, which include limited trial of small group and field trial. 


\subsection{Evaluation}

This stage was carried out by making improvements to the learning model after got advice and suggestions from the experts, and based on the result of the implementation of the economic learning model in the trial class. This result was used as a reference to revise the model developed so that the economic learning model through the CTL (Contextual Teaching and Learning) approach can be implemented in the economic learning process in the control class and experimental class to improve students' interest, learning outcomes and thinking skills (Personal, 2010)

\section{Discussion}

\subsection{Results: the Development of Economic Learning Model through CTL (Contextual} Teaching and Learning) Approach

\section{a. Analysis}

Based on the results of the study using document analysis, observation, and interviews, it was concluded that there are problems in economic learning related to the learning model used in Islamic Senior High School 2 Madiun. The process of economic learning in 11th grade of Social Studies, teachers use textbooks, student worksheets and internet sources as supporting learning materials. Based on observations, the learning model used was still conventional using lectures, and students tend to only listen, memorize, and repeat the material given by the teacher. Based on the interviews result with 30 students, who were in 11th grade of Social Studies class 1, class 2, and class 3, the used of lecture learning models has an impact on the low of students' interest and learning outcomes, students are required to have a high focus in listening to the material delivered by the teacher, students also feel less active during the learning process so that the lecture learning model feels tedious and does not suit the needs of students in the class.

Meanwhile, based on the results of a preliminary analysis of critical thinking skills within 30 students in 11th grade Social Studies by referring to Ennis' (2011) thinking skills indicators, that people who think critically should ideally have some criterias which abbreviated as FRISCO (Focus, Reason, Inference, Situation, Clarity, Overview ). The results of critical thinking skills of 11th grade Social Studies student were as follows:

Table 1. Indicators of Critical Thinking Skills (Ennis, 2011)

\begin{tabular}{c|c|c}
\hline $\begin{array}{c}\text { Critical thinking } \\
\text { criteria }\end{array}$ & \multicolumn{1}{c}{ Indicator } & $\begin{array}{c}\text { The percentage of } \\
\text { student answers }\end{array}$ \\
\hline Focus & $>\begin{array}{l}\text { Students are able to understand the problem in } \\
\text { the question given }\end{array}$ & $60 \%$ \\
\hline Reason & $>\begin{array}{l}\text { Students are able to give reasons based on facts } \\
\text { or relevant evidence at each step in making a } \\
\text { decision or conclusion }\end{array}$ & $45 \%$ \\
\hline Inference & $>\begin{array}{l}\text { Students are able to make conclusions correctly } \\
\text { Students have appropriate reasons to support the } \\
\text { conclusions made }\end{array}$ & $32 \%$ \\
\hline Situation & $>\begin{array}{l}\text { Students are able to use the information in } \\
\text { accordance to the question }\end{array}$ & $30 \%$ \\
\hline Starity & $>\begin{array}{l}\text { Students are able to explain further about what is } \\
\text { meant in the conclusions made } \\
\text { Students are able to explain the terms in the } \\
\text { question, if any } \\
\text { Students are able to provide examples of cases }\end{array}$ & $30 \%$ \\
\hline
\end{tabular}




\begin{tabular}{l|l|l}
\hline & that correlate to the question & \\
\hline Overview & $>\begin{array}{l}\text { Students check back the question and answer in } \\
\text { its entirety starting from the beginning to the end }\end{array}$ & $35 \%$ \\
\hline
\end{tabular}

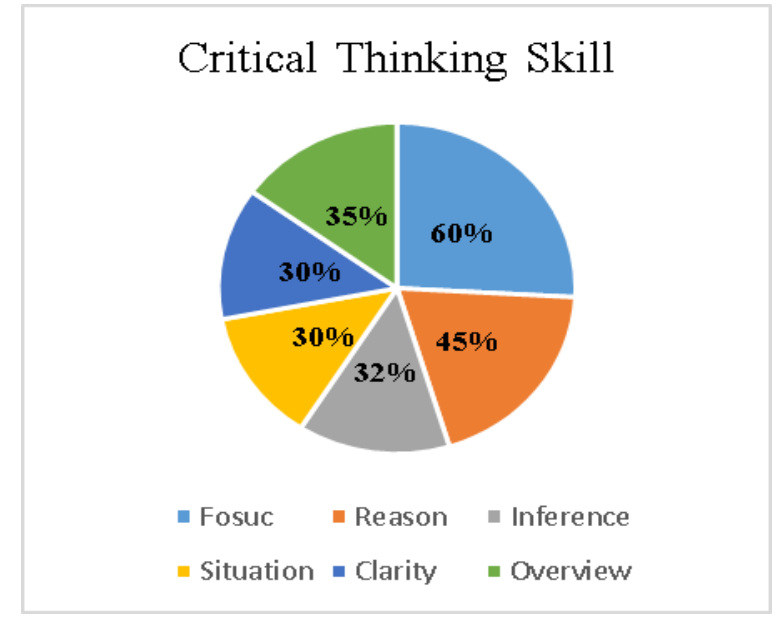

Figure 1. Critical Thinking Skill

Based on the results of critical thinking questionnaire assessment within 30 students in 11th grade Social Studies, it is known that the average of students' critical thinking skills was $38 \%$ and belongs to the low category. Based on the table above, to determine students' critical thinking skills in working on a questionnaire about economic learning, the researcher identify and observe students' critical thinking skills in solving problems. This is relevant to Sabandar's (2009) research, that there is a relationship between critical thinking skills and problem-solving skills.

Based on the results of the analysis stage, it can be concluded that economic learning in 11th grade Social Studies of Islamic Senior High School 2 Madiun still used conventional models. The teacher mostly used the lecture learning model where students only listen, take notes, and memorize the material that has been delivered. According to students, thus learning model requires high concentration and makes learning seem tedious. Based on the questionnaire results, the students' critical thinking skills were still in the low category. Therefore, it took innovation in economic learning models that appropriate with the needs of students and can improve the critical thinking skills of 11th grade Social Studies students.

\section{b. Design}

Based on the results of the analysis, theoretical study, and interview results with teachers and students, the economic learning model design was developed through the CTL (Contextual Teaching and Learning) approach to improve students' critical thinking skills in 11th grade Social Studies of Islamic Senior High School 2 Madiun. The development of this model adjusts the Core Competencies and Basic Competencies contained in the syllabus and learning plans for 11th grade economic subjects in Social Studies. Material and Basic Competencies used in the CTL (Contextual Teaching and Learning) approach can be seen as follows:

Table 2. Basic Competencies

\begin{tabular}{|l|l|}
\hline Basic Competencies & 3.1. Describe the concept of economic development, economic
\end{tabular} growth, problems and how to overcome it.

4.1. Present the findings of problems in economic development and economic growth and how to overcome it. 
The design of economic learning models through the CTL (Contextual Teaching and Learning) approach referred to the seven components according to Daryanto (2014), as follows:

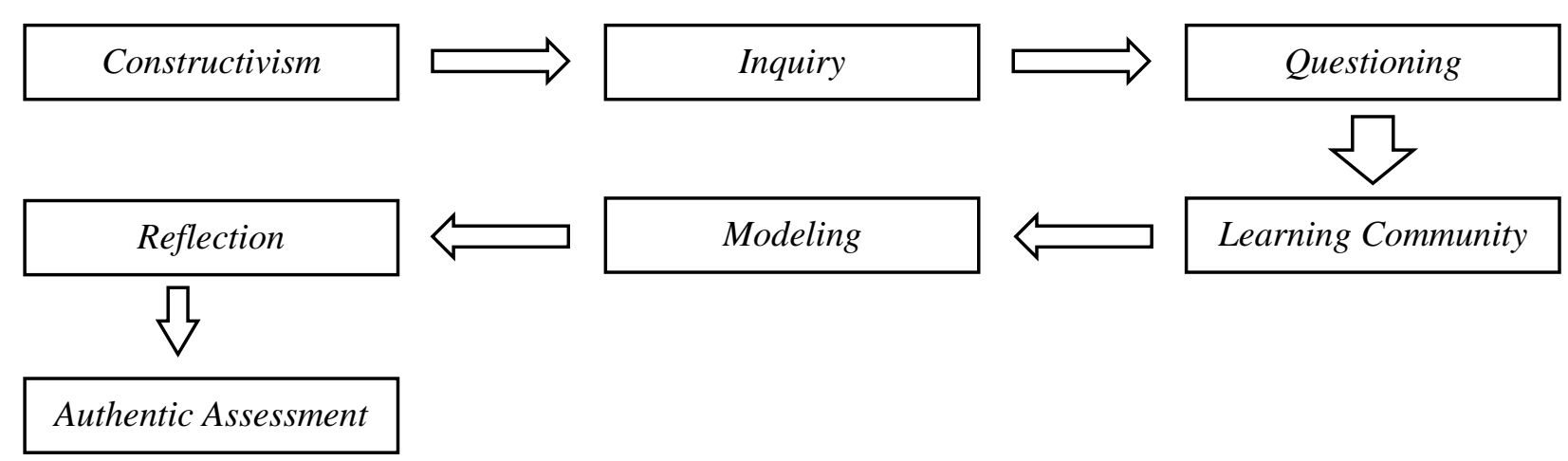

Figure 2. The Syntax of CTL (Contextual Teaching and Learning) Approach

\section{c. Development}

The results of the validation assessment of the economic learning model through the CTL (Contextual Teaching and Learning) approach consist of syllabus, learning plan, manual book, teacher module, and student module. The result of validation assessment from two learning experts namely Prof. Dr. Nunuk Suryani, M.Pd and Prof. Dr. Abdul Gafur, M.Sc, can be seen as follows:

Table 3. The Validation Result of Learning Model Experts

\begin{tabular}{llcccc}
\hline \multirow{2}{*}{ No } & \multirow{2}{*}{$\begin{array}{l}\text { Component } \\
\text { Assessed }\end{array}$} & \multicolumn{2}{c}{$\begin{array}{c}\text { Learning } \\
\text { Experts }\end{array}$} & \multirow{2}{*}{ Average } & \multirow{2}{*}{ Category } \\
\cline { 2 - 3 } & & $\mathbf{1}$ & $\mathbf{2}$ & & \\
\hline 1 & Syllabus & 3,61 & 3,80 & 3,71 & Very good \\
2 & Learning Plan & 5,00 & 4,93 & 4,97 & Very good \\
3 & Manual Book & 4,81 & 4,50 & 4,66 & Very good \\
4 & Teacher Module & 4,90 & 4,54 & 4,68 & Very good \\
5 & Student Module & 4,50 & 4,81 & 4,66 & Very good \\
\hline & \multicolumn{1}{r}{ Average } & $\mathbf{4 , 5 6}$ & $\mathbf{4 , 5 2}$ & $\mathbf{4 , 5 4}$ & Very good \\
\hline
\end{tabular}

The validation results of material and language experts used in the economic learning model through the CTL (Contextual Teaching and Learning) approach to improve students' critical thinking skills, can be seen as follows:

Table 4. The Validation Result of Learning Material Expert

\begin{tabular}{clcc}
\hline No & Components Assessed & Average & Caegory \\
\hline 1 & Teacher Module & 4,36 & Very good \\
2 & Student Module & 4,68 & Very good \\
\hline & Average & $\mathbf{4 , 5 2}$ & Very good \\
\hline
\end{tabular}

Table 5. The Validation Result of Language Expert

No Components Assessed $\quad$ Average Caegory




\begin{tabular}{llll}
\hline 1 & Teacher Module & 3,65 & Very good \\
2 & Student Module & 3,86 & Very good \\
3 & Manual Book & 3,95 & Very good \\
\hline & Average & $\mathbf{3 , 8 2}$ & Very good \\
\hline
\end{tabular}

\section{d. Implementation}

Based on the results of small group trial, the assessment included the achievement of learning outcomes and students' critical thinking skills using the CTL (Contextual Teaching and Learning) approach. Based on the results of the trial, it can be concluded that the pretest mean score was 55 and the posttest average score was 65 . The observers' assessment result from the implementation of economic learning using the CTL (Contextual Teaching and Learning) approach got a mean score of 3.27 and included into the sufficient category. Meanwhile, the field trial (whole class) result of 30 students of 11th grade Social Studies 1, the average pretest score was 50 and the posttest score was 75 . The observers' assessment result from the implementation of economic learning using the CTL (Contextual Teaching and Learning) approach in the field trial got the average score of 3.70 and included into excellent category.

e. Evaluation

Based on the results of research and development, it is known that the learning model that appropriate with the students' needs to improve critical thinking skills was economic learning models using the CTL (Contextual Teaching and Learning) approach. Based on validation results consisted of learning model experts, learning material experts, and language experts, to the developed learning instruments got the good category results. Meanwhile, the results of the implementation test include small group trial and field trial got positive results and effectively proven in improving students' critical thinking skills of 11th grade of Social Studies 1. Therefore, the economic learning model through the CTL (Contextual Teaching and Learning) approach to improve the students' critical thinking skills can be declared feasible and able to be used in the economic learning process in 11th grade Social Studies of Islamic Senior High School 2 Madiun.

\subsection{Discussion: the CTL Approach to Improve Students' Critical Thinking Skills}

Economic is one of the subjects that has been considered difficult and less attractive to students in school. The use of learning models that are not appropriate is one of the factors in economic subject that seem tedious and not attractive to students. This opinion is supported by Rahmah's research (2014), the economic learning which is lacking in quality and not achieving learning objectives are influenced by teachers or personalities that are less appropriate and learning models that are less supportive, so students have difficulty and are less enthusiast in learning economic subjects. Meanwhile, according to Dewantara (2012), factors that cause students experience difficulties in learning economic subjects include the low interaction between teachers and students and learning models that are less attractive to students.

Based on the results of a preliminary study in Islamic Senior High School 2 Madiun, it is known that students' critical thinking skills in economics learning were relatively low. The learning process that still used the lecture model caused critical thinking skills to be less trained in the classroom. This is certainly not in accordance with the 2013 Curriculum which is designed to strengthen student competency in aspects of knowledge, skills, and attitudes as a whole. According to Sari (2020) Attitude means the way people think and feel about 
someone or something; a feeling or way of thinking that affects a person's behavior or a way of thinking and behaving that people regard as unfriendly, rude, etc. Therefore, the development of economic learning models through the CTL (Contextual Teaching and Learning) approach is the right solution to improve students' interest, learning outcomes, and critical thinking skills on economic subjects. This notion is supported by Mahyanas' research (2018), that good learning is a learning that can improve critical thinking skills by actively involving students, both physically, mentally and socially in the process of learning. Developing students' critical thinking skills is very important because it can be a determinant aspect of the learning success carried out by teachers in the classroom.

Based on the results of the design, development and try-out stage, the CTL approach got great results. Meanwhile, according to the assessment results of the of learning, language, and material experts, stated that the economic learning model using the CTL (Contextual Teaching and Learning) approach is relevant and able to be used in the economic learning process of 11th grade Social Studies at Islamic Senior High School 2 Madiun. According to Johnson (2002), the CTL (Contextual Teaching and Learning) approach is an educational process that aims to help students see meaning in the material, students learn by connecting academic subjects with the context of students' personal, social, and cultural circumstances. Trianto (2008) stated that Contextual Teaching and Learning is a learning concept that helps teachers connect material with contextual environmental conditions and helps students to connect their knowledge to the application in students' daily life. Meanwhile, According to Nurhadi (2002), one of the characteristics in contextual learning is creative and critical thinking.

According to Fisher (2009), critical thinking is the attitude of thinking deeply about the problem and some aspects that exist in human thought. Knowledge of logical examination and reasoning methods and the ability to apply these methods. Critical thinking requires an effort to be able to examine every belief or knowledge based on the evidence and subsequent conclusions that result. According to Santrock (2002) critical thinking is thinking reflectively and productively and involves evaluation through evidence. Meanwhile, Harsanto (2005) stated that the purpose of critical thinking skills is to make rational decisions directed to decide whether to believe or do something.

The importance of developing critical thinking skills in learning is related to the purpose of developing the skills of Indonesian next generation in facing global competition. So that learning does not only prioritize cognitive aspects, but also pay attention to students' affective aspects that can be useful in real life. According to Wayan Redhana and Liliasari (2008), the learning that does not prioritize critical thinking skills tends to only prepare students in rote learning that makes students easy to forget the material learned so that students do not get the meaning of learning.

Through the development of an economic learning model with the CTL (Contextual Teaching and Learning) approach, students not only learn about the concept of material or knowledge in the classroom, but students are directed to be more sensitive and recognize the environment and various economic problems in society. . Based on the results of analysis and development stage, the CTL (Contextual Teaching and Learning) approach is effective and can be used as an alternative to improve students' interest in learning economic subjects. According to Aqib (2013), the CTL (Contextual Teaching and Learning) approach can be used and applied in different curricula, fields of study, and classes. Meanwhile, Suprihatiningrum (2013) explained that the CTL (Contextual Teaching and Learning) approach is a relevant learning concept to help teachers connect material taught with students' real-world situations. Sudarmiani (2019) stated that students who have critical thinking skills can adjust new information to manipulate information as an effort to find solutions or 
problems. Therefore, through the development and the use of economic learning models through CTL (Contextual Teaching and Learning) approach, students will not feel bored in the learning process and students' will improve critical thinking skills that will useful in their future real life, especially in facing the complex global competition.

\section{Conclusion}

The economic learning in high school still uses conventional models with rote learning method, so far, so it give impact to the students' boredom. Students assume that economic learning using thus kind of model requires high concentration. The development of economic learning models using the CTL (Contextual Teaching and Learning) approach effectively proved and relevant to improve students' interest, learning outcomes and critical thinking skills. The CTL (Contextual Teaching and Learning) approach has several characteristics, one of which makes students think critically and innovatively. Through the development of an economic learning model with the CTL (Contextual Teaching and Learning) approach, students not only learn about the concept of material or knowledge in the classroom, but students are directed to be more sensitive and recognize the environment and various economic problems in society. Therefore, developing students' critical thinking skills is very important especially in economic subjects, because it can be a determinant aspect to the success of economic learning in the classroom. On the other hand, through critical thinking skills, students will have a sensitivity to various economic problems and developments that exist in the surrounding environment.

\section{References}

Arima Sari, R. (2017). Faktor-Faktor Penyebab Kesulitan Belajar Ekonomi Peserta Didik SMA N Kelas X IPS Semester Gasal Di Kabupaten Sleman Tahun Ajaran 2016/2017. Jurnal Pendidikan Ekonomi. Volume 6, Nomor 5, Tahun 2017. Hlm. 465-476.

Aqib, Z. (2013). Model-Model Media dan Strategi Pembelajaran Kontekstual (Inovatif). Bandung: Rama Widya.

Dahar, R. (2011). Teori-Teori Belajar \& Pembelajaran. Jakarta: Erlangga.

Daryanto. (2014). Pendekatan Pembelajaran Saintifik Kurikulum 2013. Yogyakarta: Gava Media.

Departemen Pendidikan Nasional. (2003). Undang-Undang Nomor 2 Tahun 2003 Tentang Sistem Pendidikan Nasional. Jakarta: Depdiknas.

Dewantara, IPM. (2012). Identifikasi Faktor Penyebab Kesulitan Belajar Keterampilan Berbicara Siswa Kelas VII E SMPN 5 Negara dan Strategi Guru untuk Mengatasinya. Jurnal Pendidikan Dan Pembelajaran Bahasa Indonesia. Vol 1, No. 2 (2012). Hlm 1-15.

Ennis, R. (2011). The Nature of Critical Thinking: An Outline of Critical Thinking Dispositions and Abilities. University of Illinois.

Eriawaty. (2009). Kontribusi Profesional Guru Terhadap Pengembangan Keterampilan Berpikir Rasional Siswa Dalam Pembelajaran Ekonomi SMA Di Kota Palangkaraya Kalimantan Tengah. Tesis: Universita Pendidikan Indonesia.

Fisher, A. (2009). Critical Thinking: An Introduction, Penerjemah Benyamin Hadinata. Jakarta: Penerbit Erlangga.

Harsanto, R. (2005). Melatih Anak Berpikir Analitis, Kritis, dan Kreatif. Jakarta: PT. Grasindo.

Irwandi. (2014). Pengaruh Pendekatan Kontekstual Melalui Strategi Inkuiri Dan Masyarakat Belajar Terhadap Hasil Belajar Kognitif. Jurnal Pendidikan Biologi. Vol. 1 No. 1. 
Johnson, B. (2002). Contextual Teaching \& Learning, What it is and why it's here to stay. California: Corwin Press, Inc.

Johnson, B. (2010). Contextual Teaching and Learning: Menjadikan Kegiatan Belajar Mengajar Mengasyikkan Dan Bermakna Penerjemah Ibnu Setiawan. Bandung: Kaifa.

Mahyana. (2018). Penerapan Model Problem Based Learning Untuk Meningkatkan Keterampilan Berpikir Kritis Siswa Pada Kelas IV MIN 25 Aceh Besar. Skripsi: Fakultas Tarbiyah dan Keguruan Universitas Islam Negeri Ar-Raniry Darussalam Banda Aceh.

Nurhadi. (2002). Pendekatan Kontekstual. Jakarta: Departemen Pendidikan Nasional

Pratiwi, W. (2013). Penerapan Media Komik Sebagai Media Pembelajaran Ekonomi Di SMA 3 Ponorogo. Jurnal Pendidikan Ekonomi (JUPE). Vol. 1 No. 3 Tahun 2013. Hlm. 1-16.

Pribadi, B. (2010). Model Desain Sistem Pembelajaran. Jakarta: Dian Rakyat.

Rahmah, A \& Dewita, Y. (2014). Faktor-Faktor Yang Mempengaruhi Kesulitan Belajar Mata Pelajaran Ekonomi Siswa Kelas XII IPS SMAN 2 Sijunjung. ECONOMICA: Journal of Economic and Economic Education. Vol. 3 No. 1. Hlm. 81-88.

Rangkuti, A. N. and Hasibuan, W. S. (2019). Learning of Spatial Operations in 1st Grade of Junior High School (MTs.S NU Paringgonan) Ulu Barumun Sub-district Padang Lawas Regency. Budapest International Research in Linguistics and Education Sciences (BirLE) Journal. 2(1): 181-193.

Redhana, I.W \& Liliasari. (2008). Progam Pembelajaran Keterampilan Berpikir Kritis Pada Topik Laju Reaksi untuk Siswa SMA. Forum Pendidikan. Volume 27 No. 2. Hlm 103112.

Rois, M. (2002). Menumbuhkan Kemampuan Berpikir Kritis Dan Kreatif Siswa Dalam Pembelajaran PIPS Melalui Isu-Isu Kemasyarakatan (Studi Penelitian Kualitatif Naturalistic Inquiry Pada Pembelajaran PIPS Di SLTPN 13 Kota Bandung). Tesis: Universitas Pendidikan Indonesia.

Sabandar, J. (2009). Berpikir Reflektif. http://math.sps.upi.edu/wpcontent/uploads/2009/11/Berpikir-Reflektif.pdf. Diakses tanggal 18 Maret 2020.

Sari, I., Pulungan, A. H. and Husein, R. (2020). Students' Cognition and Attitude in Writing Descriptive Text. Britain International of Linguistics, Arts and Education (BIoLAE) Journal. 395-404.

Siswoyo, D. (2008). Ilmu Pendidikan. Yogyakarta: UNY Press.

Sitorus, H.V., Nugrahadi, E.W., and Budiarta, K. (2019). The Effect of Learning Strategy and Thinking Ability on the Students' Learning Outcomes in Economics Subject of XI Social Students in Senior High School State 1 in Pematang Siantar. Budapest International Research in Linguistics and Education Sciences (BirLE) Journal. 2(4): 451-460.

Sucihatiningsih \& Sulistyowati (2006). Faktor-Faktor Yang Mempengaruhi Kesulitan Belajar Mata Pelajaran IPS Ekonomi. Jurnal Dinamika Pendidikan. Vol. 1 No. 2 (2006). Hlm. 162-181.

Sudarmiani \& Utomo, S. (2019). Implementasi Pembelajaran Problem Solving Berbasis HOTS Pada Mata Pelajaran Ekonomi. Jurnal Ekonomi Pendidikan dan Kewirausahaan. Vol. 7 No. 2. Hlm. 159-168.

Sugiyono. (2015). Metode Pendidikan Pendekatan Kuantitatif, Kualitatif, dan R\&D. Bandung: Alfabeta.

Suprihatiningrum, J. (2013). Strategi Pembelajaran Teori dan Aplikasi. Yogyakarta: Ar Ruzz Media. 